\title{
Digestion of concentrates in sheep
}

\section{4.* The effects of urea on digestion, nitrogen retention and growth in young lambs}

\author{
BY E. R. ØRSKOV, C. FRASER AND I. McDONALD \\ Rowett Research Institute, Bucksburn, Aberdeen, $A B 2{ }_{9} S B$
}

(Received 30 fune 1971 - Accepted 25 October 1971)

\begin{abstract}
I. The effects of adding increasing supplements of urea to mainly barley diets for earlyweaned lambs were investigated in two experiments. In the first experiment the passage of nutrients along the alimentary tract was studied by taking samples of abomasal, ileal and rectal contents and using a marker technique. In the second experiment, feed consumption and rate of gain were recorded over the growth period up to $40 \mathrm{~kg}$ live weight, and nitrogen balances were carried out. In the second experiment a barley-fish meal diet was also included.

2. The fermentation of organic matter in the rumen increased with the amount of urea in the diet and levelled off when the diet contained about $12 \%$ crude protein.

3. Urea supplementation had significant effects in increasing $\mathbf{N}$ retention and rate of liveweight gain and in decreasing feed conversion ratio, but supplementation beyond about 12. \% crude protein in dry matter had no further effect on these measurements. In each instance results with the barley-fish meal diet were better than the results with any of the barley-urea diets.

4. From the concentrations of diaminopimelic acid (DAPA) in abomasal fluid it was estimated that microbial protein was produced in the rumeri at a rate of $15.6 \mathrm{~g} / 100 \mathrm{~g}$ organic matter fermented. This ratio did not appear to alter significantly with urea supplementation, but the comparison depends on the assumption that the concentration of DAPA in the bacterial protein did not itself change with urea supplementation.

5. Using results from both experiments, it was calculated that the retained $\mathrm{N}$ on the ureasupplemented barley diets was approximately $47 \%$ of the amount of protein $\mathrm{N}$ absorbed in the small intestine.

6. It is suggested that barley diets for early-weaned lambs can with advantage be supplemented with non-protein $\mathrm{N}$ to increase the crude protein in the dry matter up to about $12 \%$. When barley diets are given with a protein supplement the addition of non-protein $\mathrm{N}$ is unlikely to be beneficial unless the protein supplement is given in such a way that it is not subject to degradation to yield ammonia in the rumen.
\end{abstract}

Previous work on the mature sheep published in this series (Ørskov, Fraser $\&$ McDonald, I97 $^{\mathrm{I}} b$ ) showed that supplementing a basal barley diet with urea did not affect the amount of protein passing through the abomasum. This observation indicated that nitrogen was not the limiting factor for microbial growth in the rumen; however, when the unsupplemented diet was given, then more $\mathrm{N}$ passed the abomasum than was contained in the food, i.e. a large amount of $\mathrm{N}$ was recycled via saliva and blood to the rumen. It was suggested that a young fast-growing lamb might not be able to recycle as much $\mathrm{N}$ as a mature sheep and might therefore show a response to urea supplementation.

Since young lambs have the ability to retain much more $N$ than can be supplied by the microbial $\mathrm{N}$ produced from fermentation of the food carbohydrate (Ørskov, I970), it seemed that they would be very appropriate to use in determining the amount

* Paper no. 3: Br. F. Nutr. (1971), 26, 477. 
of $\mathrm{N}$ required to give optimum production of microbial $\mathrm{N}$. The production could be determined by measuring the amount of $\mathrm{N}$ passing the abomasum and the utilization could be assessed in terms of $\mathrm{N}$ retention and growth. These ideas have been tested in the two experiments reported here; in Expt I the effect of urea supplementation on the amount of $\mathrm{N}$ passing the abomasum was measured, and in Expt 2 the effects on $\mathrm{N}$ retention and growth were determined.

\section{EXPERIMENTAL}

\section{Animals}

In Expt I, four female lambs were used; they were initially 7 wecks of age and were fistulated in the abomasum and in the terminal ileum as described by Ørskov, Fraser $\&$ Kay (1969). They weighed on average $\mathrm{I} 6 \mathrm{~kg}$ at the beginning and $27 \mathrm{~kg}$ at the end of the experiment. In Expt 2, eighteen female and eighteen entire male lambs were used. They were weaned from thcir dams at $5^{-6}$ weeks of age and allocated to the experimental treatments at about 7 weeks of age. Their mean initial weight was $15.5 \mathrm{~kg}$ (standard deviation $2 \cdot 0 \mathrm{~kg}$ ). The lambs used in both experiments were Suffolk $\times$ North Country Cheviot.

\section{Design and treatments}

In Expt I, a $4 \times{ }_{4}$ Latin square design was used with four diets each given for periods of $\mathrm{I}_{4} \mathrm{~d}$. The diets ( $\mathrm{IA}, \mathrm{rB}, \mathrm{IC}$ and $\mathrm{xD}$ ) consisted of rolled barley and cassava meal with supplements of increasing amounts of urea to give crude protein concentrations of $10.0,12.4,14.6$, and $16.4 \%$ in the dry matter. The ingredients of the basal diets are given in Table I. Diets I $\mathrm{B}, \mathrm{IC}$ and $\mathrm{ID}$ were made by replacing respectively 0.7 , $\mathrm{I} \cdot 4$ or $2 \cdot \mathrm{I} \%$ of diet IA by urea.

A randomized block design was used in Expt 2. The lambs were separated into blocks of six according to date of birth and sex, and within blocks were allocated at random to six different diets.

Diets $2 \mathrm{~B}, 2 \mathrm{C}, 2 \mathrm{D}$ and $2 \mathrm{E}$ were made by replacing respectively $0 \cdot 55, \mathrm{I} \cdot 10, \mathrm{r} \cdot 65$ and $2.20 \%$ of diet $2 \mathrm{~A}$, the basal diet, by urea; diet $2 \mathrm{~F}$ was made by replacing $9.5 \%$ of diet $2 \mathrm{~A}$ by fish meal (Table $\mathrm{I}$ ). The crude protein concentrations in the six diets were respectively $9 \cdot 0,10 \cdot 5,12 \cdot 3, I_{4} \cdot 1,15^{\cdot} 6$ and $14 \cdot 7 \%$ of the dry matter.

In both experiments and as in previous work, the amount of feed offered daily was near the maximal intake as estimated from live weight using the formula: $Y=5.00-$ $0.0353 \mathrm{~W}$, where $Y$ is the daily feed offered (in $\mathrm{kg}$ ) expressed as a percentage of live weight $(W)$. In Expt $\mathrm{x}$ the amount offered daily was calculated from the mean live weight at the beginning of each $\mathrm{I}_{4} \mathrm{~d}$ period; in Expt 2 it was adjusted according to the live weight at the beginning of each week.

\section{Management and sampling}

Expt $\mathrm{x}$. The lambs were kept on slats in individual pens. They were given half their daily food allowance at 08.00 hours and the remainder at 20.00 hours. The weight of uneaten feed was recorded daily before and after drying at $100^{\circ}$. Water was available at all times. 
Table I. Ingredients of basal diets (\% by weight)

$\begin{array}{ccccccc}\begin{array}{c}\text { Expt } \\ \text { no. }\end{array} & \begin{array}{c}\text { Rolled } \\ \text { barley }\end{array} & \begin{array}{c}\text { Cassava } \\ \text { meal }\end{array} & \begin{array}{c}\text { Calcium } \\ \text { carbonate }\end{array} & \begin{array}{c}\text { Dicalcium } \\ \text { phosphate }\end{array} & \begin{array}{c}\text { Sodium } \\ \text { chloride }\end{array} & \begin{array}{c}\text { Chromic } \\ \text { oxide } \\ \text { mixture* }\end{array} \\ \text { I } & 87.0 & 9.0 & I .5 & 1.5 & 0.0 & \text { I.0 } \\ 2 & 85.0 & 12.0 & I .0 & 1.5 & 0.5 & 0.0\end{array}$

Each diet contained in addition (per $\mathrm{kg}$ ): 5000 i.u. vitamin A palmitate, rooo i.u. cholecalciferol, 20 i.u. vitamin $\mathrm{E}$, $200 \mathrm{mg} \mathrm{MgO}$, I $50 \mathrm{mg} \mathrm{ZnSO}_{4} \cdot 7 \mathrm{H}_{2} \mathrm{O}$, 80 $\mathrm{mg} \mathrm{MnSO}_{4} .4 \mathrm{H}_{2} \mathrm{O}$, $0.2 \mathrm{mg} \mathrm{KIO}_{3}$ and $0.43 \mathrm{mg} \mathrm{CoSO} \cdot 7 \mathrm{H}_{2} \mathrm{O}$.

* Wheat flour and chromic oxide (4:I) mixed, baked and ground.

On the last day of each period samples of abomasal, ileal and rectal contents were obtained at intervals of $2 \mathrm{~h}$ as described previously (Ørskov, Fraser \& McDonald, r $97 \mathrm{I} a$ ). The samples were pooled for the $24 \mathrm{~h}$ period and kept frozen at $-20^{\circ}$. As in previous work, the disappearances of digesta between the mouth and the abomasal sampling point, between the abomasal and ileal sampling points and between the last and the rectum (referred to as disappearances in the rumen, the small intestine and the large intestine respectively) have been calculated from changes in the concentrations of chromium oxide.

Expt 2. The lambs were kept in individual pens and bedded with sawdust; fresh water was always available. Their daily allowance of feed was given as in Expt $\mathrm{x}$. Uneaten feed was recorded weekly and dried at $100^{\circ}$.

$\mathrm{N}$ retention was measured in two blocks of female and two blocks of male lambs during Expt 2. The lambs were put into metabolism cages for $15 \mathrm{~d}$, and urine and faeces were collected for the last $10 \mathrm{~d}$. The urine was collected into a solution of formaldehyde and acetic acid to ensure a final concentration of about $\mathrm{r} \%$ formaldehyde and a $\mathrm{pH}$ of about 5. The lambs in Expt 2 were slaughtered when they had attained a live weight of $39 \mathrm{~kg}$. The cold carcasses were wcighed in air and also in water to enable carcass densities to be calculated.

\section{Analytical procedure}

The $\mathrm{N}$ content of liquid digesta, food, faeces and urine was measured by the Kjeldahl method using automated equipment described by Davidson, Mathieson \& Boyne (1970). Chromium was determined by the method of Stevenson \& Clare (1963) as modified by Mathieson (1970), diaminopimelic acid (DAPA) by the method of Mason (r969) and ammonia by the method of Conway (I957). Starch was estimated as $\alpha$-linked glucose polymers by the method of MacRae \& Armstrong (I968).

\section{RESULTS \\ $\operatorname{Expt} \mathbf{I}$}

Treatment mean values for rates of dry-matter intake and live-weight gain and for the apparent digestibility of dry matter, organic matter and crude protein are given in Table 2. The apparent digestibility of crude protein increased with urea supplementation $(P<0.05)$. There were no significant treatment effects on digestibility of other 
Table 2. Expt 1. Mean intake of dry matter, live-weight gain and apparent digestibility of dry matter, organic matter and crude protein by four lambs receiving a diet of rolled barley supplemented with different amounts of urea

(Each value is the mean of four observations)

\begin{tabular}{|c|c|c|c|c|c|c|c|}
\hline \multirow[b]{2}{*}{ Treatment* } & \multirow[b]{2}{*}{$\begin{array}{c}\text { Designa- } \\
\text { tion of } \\
\text { diet }\end{array}$} & \multirow[b]{2}{*}{$\begin{array}{c}\text { Crude } \\
\text { protein } \\
(\% \text { of } \mathrm{DM})\end{array}$} & \multirow{2}{*}{$\begin{array}{l}\text { Dry- } \\
\text { matter } \\
\text { intake } \\
(\mathrm{g} / \mathrm{d})\end{array}$} & \multirow{2}{*}{$\begin{array}{l}\text { Live- } \\
\text { weight } \\
\text { gain } \\
\text { (g/d) }\end{array}$} & \multicolumn{3}{|c|}{ Apparent digestibility (\%) } \\
\hline & & & & & $\begin{array}{c}\text { Dry } \\
\text { matter }\end{array}$ & $\begin{array}{l}\text { Organic } \\
\text { matter }\end{array}$ & $\begin{array}{l}\text { Crude } \\
\text { protein }\end{array}$ \\
\hline 0 & IA & 10.0 & 749 & 166 & $74 \cdot 9$ & $77^{\prime} \mathbf{I}$ & $56 \cdot 5$ \\
\hline $0.7 \%$ & IB & 12.4 & 745 & 217 & $76 \cdot 5$ & $78 \cdot 6$ & $66 \cdot 3$ \\
\hline$I \cdot 4 \%$ & IC & $14 \cdot 6$ & $75^{1}$ & 223 & $75 \cdot 2$ & $77 \cdot 9$ & $67 \cdot 7$ \\
\hline $2 \cdot 1 \%$ & ID & $16 \cdot 4$ & 744 & 228 & $77 \cdot \mathbf{I}$ & $79 \cdot 5$ & $72 \cdot 3$ \\
\hline \multirow{2}{*}{\multicolumn{2}{|c|}{$\begin{array}{l}\text { SE of treat- } \\
\text { ment differences }\end{array}$}} & - & - & 3 I & $2 \cdot 4$ & $2 \cdot 3$ & 4.8 \\
\hline & & $\mathrm{M}, \mathrm{d}$ & er. & & urea. & & \\
\hline
\end{tabular}

components, and, although live-weight gain was slightly higher with urea supplementation, this effect was not quite statistically significant $(0.05<P<0.1)$.

Table 3 shows the composition of abomasal and ileal fluid and of the faeces. As the level of urea supplementation increased, the percentage of dry matter in abomasal fluid decreased and the ash (as \% of dry matter) increased $(P<0.05)$. Both ammonia $\mathrm{N}$ and non-ammonia crude protein (NACP) concentrations increased with urea supplementation $(P<0.001)$. With NACP, the quadratic component of the trend almost reached statistical significance $(0.05<P<0 . \mathrm{I})$, suggesting that the effect of additional urea was decreasing as the urea level increased. The ratio of DAPA to N did not alter significantly between treatments.

The dry-matter and ash concentrations in ileal fluid showed no significant treatment effects, but ammonia concentration rose with urea level $(P<0.001)$ and NACP also increased $(P<0.05)$. There was a significant increase in crude protein concentration in the faeces $(P<0.05)$.

Table 4 shows treatment means of the rates of passage of starch and of organic matter along the digestive tract. The rate of passage of starch at the abomasal sampling point decreased as urea was added at the two lower levels, and then levelled off, both the linear and quadratic components of trend being significant $(P<0.001$ and $P<0.05$, respectively). The starch values were judged in the light of a statistical analysis of their logarithms because the variability of the starch values themselves appeared to increase as their magnitude increased. As the level of urea supplementation increased there were significant increases in the apparent disappearance of organic matter from the rumen $(P<0.05)$. It should be noted that this net difference between the amount of organic matter taken in and that passing the abomasal sampling point is not a true estimate of the dietary organic matter fermented. It is underestimated by the amount of bacterial organic matter passing the abomasum. The disappearance of organic matter in the intestines and its excretion in the faeces did not change significantly with treatment but there was a suggestion of a reduction in the disappearance in the large intestine with increasing urea $(0.05<P<0.1)$. 
Vol. 27

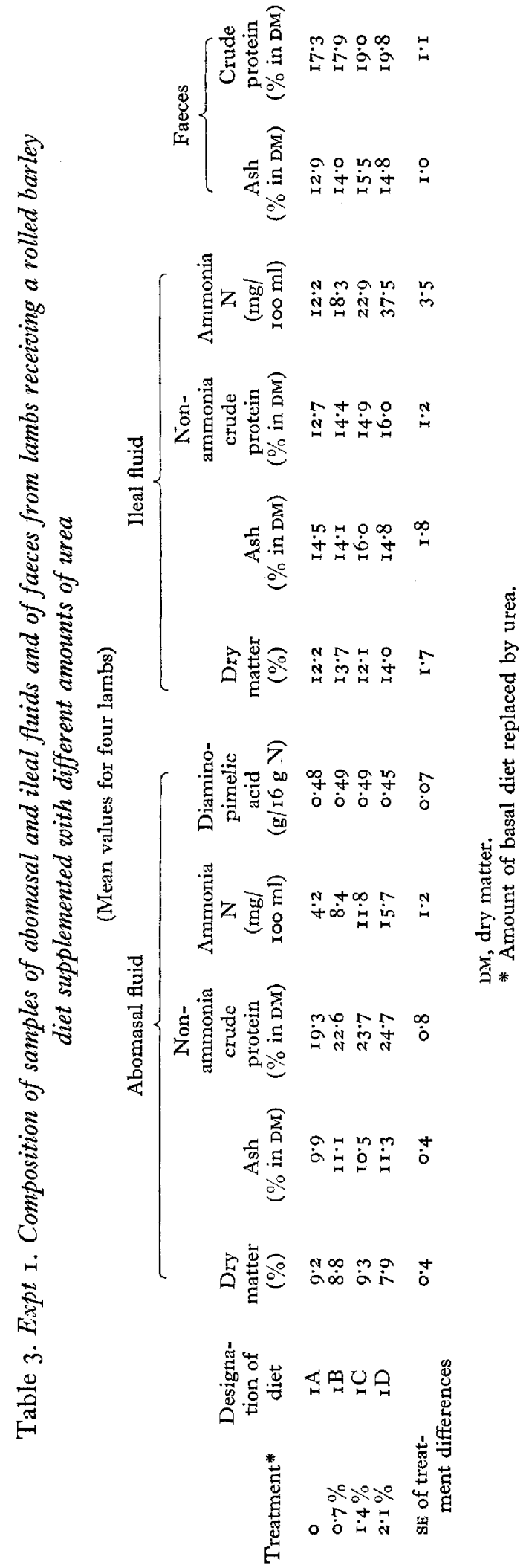


Table 4. Expt $\mathrm{x}$. Intake and passage of starch through abomasum and disappearance of organic matter in lambs receiving a rolled barley diet supplemented with different amounts of urea

\begin{tabular}{|c|c|c|c|c|c|c|c|c|}
\hline \multirow[b]{3}{*}{ Treatment* } & \multicolumn{7}{|c|}{ (Mean values for four lambs) } & \multirow{3}{*}{$\begin{array}{c}\text { Organic } \\
\text { matter } \\
\text { in faeces } \\
(\mathrm{g} / \mathrm{d})\end{array}$} \\
\hline & \multirow[b]{2}{*}{$\begin{array}{l}\text { Designa- } \\
\text { nation of } \\
\text { diet }\end{array}$} & \multirow[b]{2}{*}{$\begin{array}{c}\text { Starch } \\
\text { intake } \\
\text { (g/d) }\end{array}$} & \multicolumn{2}{|c|}{$\begin{array}{c}\begin{array}{c}\text { Starch passing } \\
\text { abormasum }\end{array} \\
\end{array}$} & \multicolumn{3}{|c|}{$\begin{array}{l}\text { Apparent disappearance of } \\
\text { organic matter from }\end{array}$} & \\
\hline & & & $(\mathrm{g} / \mathrm{d})$ & $\overbrace{(\mathrm{g} / \mathrm{d})}$ & $\begin{array}{l}\text { Rumen } \\
(\mathrm{g} / \mathrm{d})\end{array}$ & $\begin{array}{l}\text { Small } \\
\text { intestine } \\
(\mathrm{g} / \mathrm{d})\end{array}$ & $\begin{array}{l}\text { Large } \\
\text { intestine } \\
(\mathrm{g} / \mathrm{d})\end{array}$ & \\
\hline$\circ$ & IA & $47^{\circ}$ & $67 \cdot 3$ & $1 \cdot 78$ & 257 & 224 & 70 & 163 \\
\hline $0.7 \%$ & I $\mathbf{B}$ & 464 & $3 \times \cdot 6$ & $r \cdot 3^{8}$ & 293 & 210 & 53 & I $5 \mathrm{I}$ \\
\hline $1 \cdot 4 \%$ & IC & 464 & 15.7 & $I \cdot I 6$ & 312 & 185 & $5^{6}$ & I 59 \\
\hline $2.1 \%$ & $\mathbf{D}$ & 457 & $15 \cdot 6$ & $I \cdot I 3$ & 334 & ז96 & 30 & 146 \\
\hline \multicolumn{2}{|c|}{$\begin{array}{l}\text { SE of treat- - } \\
\text { ment differences }\end{array}$} & - & - & 0.10 & 27 & 39 & I5 & 20 \\
\hline
\end{tabular}

Table 5. Expt I. Intake of crude protein $(C P)$, the non-ammonia crude protein (NACP) passing the abomasum and the terminal ileum, and the CP excreted in the faeces by four lambs receiving a rolled barley diet supplemented with different amounts of urea

(Each value is the mean of four observations)

\begin{tabular}{|c|c|c|c|c|c|c|c|}
\hline \multirow[b]{2}{*}{ Treatment* } & \multirow[b]{2}{*}{$\begin{array}{c}\text { Designa- } \\
\text { tion of } \\
\text { diet }\end{array}$} & \multirow[b]{2}{*}{$\begin{array}{c}\text { CP } \\
\text { intake } \\
\text { (g/d) }\end{array}$} & \multicolumn{3}{|c|}{ NACP } & \multicolumn{2}{|l|}{$\mathrm{CP}$} \\
\hline & & & $\begin{array}{c}\text { Passing } \\
\text { abomasum } \\
\text { (g/d) }\end{array}$ & $\begin{array}{l}\text { Disappear- } \\
\text { ing from } \\
\text { small } \\
\text { intestine } \\
\text { (g/d) }\end{array}$ & $\begin{array}{l}\text { Passing } \\
\text { terminal } \\
\text { ileum } \\
(\mathrm{g} / \mathrm{d})\end{array}$ & $\begin{array}{l}\text { Disappear- } \\
\text { ing from } \\
\text { large } \\
\text { intestine } \\
(\mathrm{g} / \mathrm{d})\end{array}$ & $\begin{array}{c}\text { Excreted } \\
\text { in faeces } \\
\text { (g/d) }\end{array}$ \\
\hline$\circ$ & IA & 75 & 100 & 65 & 35 & 4 & 32 \\
\hline $0.7 \%$ & $\mathbf{I B}$ & 93 & 107 & 73 & 34 & 4 & 32 \\
\hline $14 \%$ & $\mathrm{IC}$ & IIO & 106 & 68 & 38 & 5 & 36 \\
\hline $2 \cdot 1 \%$ & ID & 122 & 104 & 71 & 33 & 2 & 34 \\
\hline $\begin{array}{l}\text { SE of treat- } \\
\text { ment diff }\end{array}$ & rences & - & $8 \cdot 0$ & $8 \cdot 6$ & $4 \cdot 2$ & $3 \cdot 4$ & $4 \cdot 2$ \\
\hline
\end{tabular}

No significant treatment differences occurred in the passage of protein along the digestive tract (Table 5).

\section{Expt 2}

The $\mathrm{N}$ balance results from Expt 2 are summarized in Table 6. Dry-matter intake did not vary significantly between treatments but there were variations in intake from animal to animal. The balance results were therefore adjusted by analysis of covariance to the mean daily dry-matter intake of $783 \mathrm{~g}$. As the level of urea was increased, faecal $\mathrm{N}$ was not significantly affected but both urinary $\mathrm{N}$ excretion and $\mathrm{N}$ retention were increased (linear components were significant, $P<0.00$ I and $P<0.0$ r respectively). At the higher urea levels the increase in urinary $N$ excretion became more pronounced but the $\mathrm{N}$ retention levelled off (quadratic component significant, $P<0.05$ ). Digestibility of dry matter was significantly increased $P<0.0$ I) by supplementation but did not change significantly as the level of supplementation was increased. 
Table 6. Expt 2. Nitrogen intake, excretion and retention of lambs receiving a rolled barley diet supplemented with different amounts of urea or with fish meal

(Mean values for four lambs, adjusted by analysis of covariance to a dry-matter intake of $783 \mathrm{~g} / \mathrm{d}$ )

\begin{tabular}{|c|c|c|c|c|c|c|c|c|}
\hline Treatment* & $\begin{array}{l}\text { Designa- } \\
\text { tion of } \\
\text { diet }\end{array}$ & $\begin{array}{c}\text { Crude } \\
\text { protein } \\
(\% \text { of } \mathrm{DM})\end{array}$ & $\begin{array}{c}\mathrm{N} \\
\text { intake } \\
(\mathrm{g} / \mathrm{d})\end{array}$ & $\begin{array}{c}\text { Urinary } \\
N \\
(\mathrm{~g} / \mathrm{d})\end{array}$ & $\begin{array}{c}\text { Faecal } \\
\mathrm{N} \\
(\mathrm{g} / \mathrm{d})\end{array}$ & $\begin{array}{c}\text { Retained } \\
\mathbb{N} \\
(\mathrm{g} / \mathrm{d})\end{array}$ & $\begin{array}{c}\mathrm{DM} \\
\text { digestibility } \\
(\%)\end{array}$ & $\begin{array}{c}\text { Retained } \\
\mathrm{N} \\
\text { (g/100 } \mathrm{g} \\
\text { digestible } \\
\text { DM) }\end{array}$ \\
\hline o & $2 \mathrm{~A}$ & $9 \cdot 0$ & I I 3 & $2 \cdot 4$ & $4 \cdot 5$ & $4 \cdot 4$ & 74.9 & 0.74 \\
\hline $0.55 \%$ & $2 B$ & 10.5 & 13.5 & $3 \cdot 2$ & 4.4 & $5 \cdot 9$ & $8 \mathrm{I} \cdot 2$ & 0.93 \\
\hline $\mathbf{I} \cdot 10 \%$ & $2 \mathrm{C}$ & $12 * 3$ & $\begin{array}{r}5.5 \\
\end{array}$ & $3 \cdot 9$ & $6 \cdot 1$ & 54 & 80.6 & 0.89 \\
\hline $\mathbf{x} 65 \%$ & $2 D$ & $I 4 \cdot I$ & $17 \cdot 8$ & $6 \cdot 4$ & $4 \cdot 9$ & 6.5 & $82 \cdot 3$ & 0.99 \\
\hline $2.20 \%$ & $2 \mathrm{E}$ & 15.6 & $19 \cdot 6$ & $8 \cdot 5$ & 54 & $5 \cdot 7$ & 80.7 & 0.90 \\
\hline Fish meal & $2 \mathrm{~F}$ & 147 & 18.6 & 49 & $6 \cdot 1$ & $7 \cdot 5$ & 80.0 & $I \cdot 19$ \\
\hline $\begin{array}{l}\text { SE of treat- } \\
\text { ment diffe }\end{array}$ & erences & & & 0.8 & 0.7 & 0.4 & $\mathbf{r} \cdot 3$ & 0.06 \\
\hline
\end{tabular}

DM, dry matter.

* Amount of basal diet replaced by urea.

Table 7. Expt 2. Growth rate and feed utilization of lambs from 15.5 to $40 \mathrm{~kg}$ live weight receiving a diet of rolled barley supplemented with different amounts of urea or with fish meal

\begin{tabular}{|c|c|c|c|c|c|c|c|}
\hline \multicolumn{8}{|c|}{ (Mean values for six lambs) } \\
\hline Treatment* & $\begin{array}{l}\text { Designa- } \\
\text { tion of } \\
\text { diet }\end{array}$ & $\begin{array}{c}\text { Crude } \\
\text { protein } \\
(\% \text { of } \mathrm{DM})\end{array}$ & $\begin{array}{c}\text { Live-wt } \\
\text { gain } \\
\text { (g/d) }\end{array}$ & $\begin{array}{c}\text { Feed } \\
\text { required } \\
\text { (kg DM) }\end{array}$ & $\begin{array}{c}\text { Food } \\
\text { conversion } \\
\text { ratio } \\
\text { (kg DM } \\
\text { eaten/kg } \\
\text { live-wt gain) }\end{array}$ & $\begin{array}{c}\text { Carcass } \\
\text { wt } \\
(\mathrm{kg})\end{array}$ & $\begin{array}{l}\text { Carcass } \\
\text { density }\end{array}$ \\
\hline 0 & $2 \mathrm{~A}$ & $9 \cdot 0$ & I 58 & 105 & $4 \cdot 59$ & $20 \cdot 1$ & $I \cdot 04 I$ \\
\hline $0.55 \%$ & $2 \mathrm{~B}$ & 10.5 & I64 & 100 & 4 . 8 & $19 \cdot 3$ & $1 \cdot 046$ \\
\hline$I \cdot 10 \%$ & ${ }_{2} \mathrm{C}$ & $12 \cdot 3$ & 215 & 87 & $3 \cdot 58$ & $20 \cdot 3$ & $r \cdot 050$ \\
\hline$I .65 \%$ & $2 \mathrm{D}$ & I $4 \cdot 1$ & 196 & 90 & 3.68 & I9.9 & $\mathbf{I} \cdot 049$ \\
\hline $2.20 \%$ & $2 \mathrm{E}$ & 15.6 & 206 & 94 & 3.83 & 20.8 & 1.052 \\
\hline Fish meal & $2 \mathrm{~F}$ & $14 \cdot 7$ & $26 r$ & 72 & 2.87 & $19 \cdot 6$ & $\mathrm{r} \cdot 053$ \\
\hline SE of treat- & & & 12 & 4 & 0.20 & 0.5 & 0.004 \\
\hline
\end{tabular}

DM, dry matter.

* Amount of basal diet replaced by urea.

Compared with the two highest levels of urea supplementation, the fish-meal supplement resulted in significantly higher $\mathrm{N}$ retention and lower urinary $\mathrm{N}$ excretion $(P<0.01)$. The ratio of $\mathrm{N}$ retention to digestible dry-matter intake showed the same response as did $\mathrm{N}$ retention.

Table 7 presents the effect of urea on growth rate and feed conversion ratios. Results for two lambs, on treatments $2 \mathrm{C}$ and $2 \mathrm{E}$, were excluded from analysis because these lambs were erratic in their feed intake, gained very poorly and were eventually taken off the experiment. The values for daily live-weight gain and for total feed consumption were adjusted by analysis of covariance to eliminate variability associated with variation in initial live weight. The rate of live-weight gain increased and the total feed consumption decreased with the two lowest levels of urea supplementation but there 
was no further improvement as urea was further increased (linear trends were significant, $P<0.001$ and $P<0.01$, quadratic components were not quite significant for gain, $0.05<P<0.1$, but significant for feed consumption, $P<0.01$ ).

The lambs receiving fish meal grew significantly faster than any of the others and required significantly less feed to reach slaughter weight $(P<0 \cdot 00$ r). Feed conversion ratio, carcass weight and carcass density were not significantly related to initial weight and the mean values were therefore not adjusted. Feed conversion rate showed significant linear and quadratic components of trend with increasing level of urea supplementation $(P<0.00 \mathrm{r})$, and thus agreed with the other results in showing no benefit from the two highest additions. Feed conversion ratio was significantly lower for the lambs receiving fish meal than for any of the other treatment groups. Carcass density increased linearly $(P<0.01)$ with urea supplementation and on the fishmeal treatment was similar to the values for the higher urea levels.

\section{DISCUSSION}

The results of these experiments substantiate the suggestion that, although mature sheep showed no response to the supplementation of a barley diet with urea, a response might be expected from young lambs.

\section{Effect of urea on site of digestion}

The most striking result in Expt I was the increase in organic-matter digestion in the rumen associated with increasing urea supplementation. The results in Table 4 indicate that this increase was almost entirely accounted for by the increase in the rumen fermentation of starch when urea was added to the diet.

It could not be demonstrated with statistical significance that the amount of protein passing the abomasum was altered as a result of urea supplementation or that the capacity of the young ruminant to recycle $\mathrm{N}$ is less than that of the mature animal. However, in the work with the mature sheep (Ørskov et al. $197 \mathrm{I} b$ ), no effect on extent of rumen fermentation was noted with urea supplementaton when the unsupplemented diet contained even less $\mathrm{N}$ than the diet used here. This observation may suggest that an age difference in the rate of turnover of dietary organic matter may be responsible for the difference in results. The trend noted in the increase in $\mathrm{N}$ passing the abomasum is likely to be a genuine one in the light of the responses noted in Expt 2, but it must be pointed out that it is possible that there were differences in protein quality as a result of urea supplementation. It is likely that more dietary protein was escaping the rumen undegraded with the unsupplemented diet as more dietary organic matter passed the abomasum. It should also be pointed out that the higher crude protein concentration of the unsupplemented diet in Expt I (10\% as against $9 \%$ in Expt 2) would make it slightly more difficult to detect responses to urea supplementation. Finally it is possible that the increase in $\mathrm{N}$ retention and growth in Expt 2 occurred as a result of the increase in rumen fermentation per se with subsequent alteration in ratio of the energy derived from the end-product of fermentation 
Table 8. Estimates, based on a diaminopimelic acid concentration of $0.48 \mathrm{~g} / \mathrm{1} \circ \mathrm{g} \mathrm{g}$ nonammonia crude protein in abomasal fluid, of rate of passage of bacterial protein and organic matter from the rumen, and hence of dietary organic matter fermented in the rumen and the ratio of bacterial protein to organic matter fermented

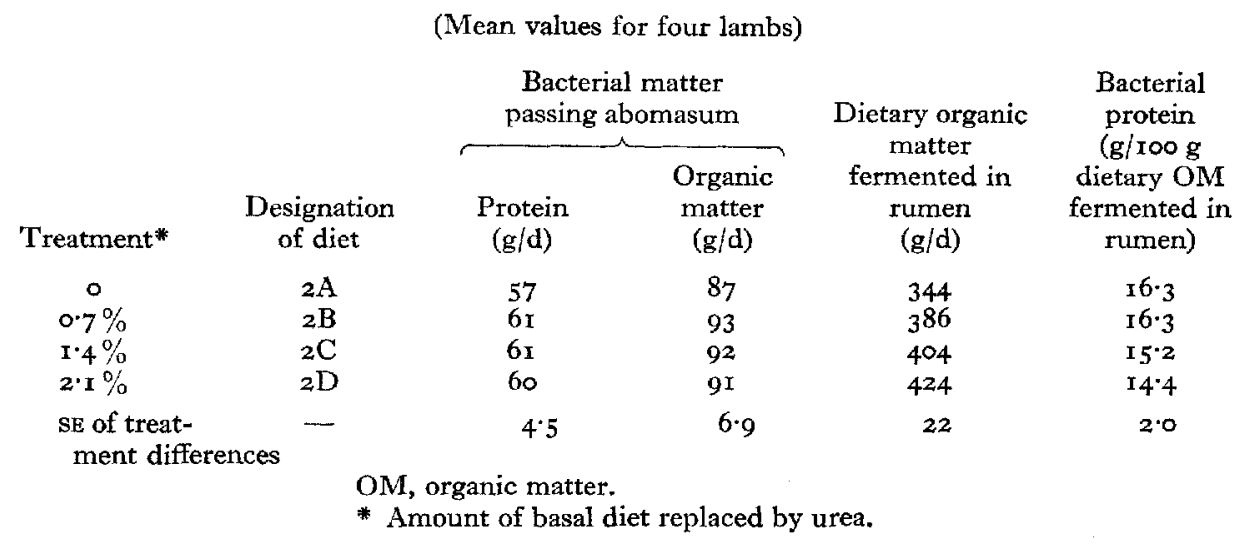

and from glucose. Whether this ratio can influence the partition of energy into protein and fatty tissue in the young ruminant is not known.

\section{Effect of urea supplementation on $N$ retention and body gain}

There was no further response in $\mathrm{N}$ retention, growth rate or feed conversion ratio to supplementation beyond the level in diet $2 \mathrm{C}$, which suggests that the optimal level of addition of urea to a barley diet for lambs is that which produces a level of about 12 \% crude protein in the dry matter. It is possible that the optimum level might be slightly higher under conditions of unrestricted food than with the system of restricted but high-level feeding that was used here.

\section{Estimation of bacterial protein production}

Estimates are given in Table 8 of the daily amounts of bacterial protein passing the abomasum. These were calculated by multiplying the corresponding NACP values in Table 5 by the factor $0.573(6.25 \times 19 \cdot 1 \times 0.0048)$ which is based on the observed mean ratio of DAPA to NACP in abomasal fluid (Table 3), and on the assumption that the N:DAPA ratio in the rumen bacteria was unaffected by the treatments imposed and could be taken as I9.I (Hutton, Bailey \& Annison, I97I). Some doubt must be cast upon this assumption by the absence of any tendency for the ratio of DAPA to NACP to increase with increasing urea. In view of the increased rumen fermentation it is difficult to believe that there was no increase in the ratio of bacterial protein to total protein passing the abomasum. It may be that there were changes in the rumen microflora associated with the change in $\mathrm{pH}$ brought about by increasing urea supplementation, but we have no direct evidence of this and therefore used the constant factor 0.573 . 
The estimates of bacterial organic matter in Table 8 were obtained from the protein values by assuming an $\mathrm{N}$ content of $10.5 \%$ (Hungate, 1966 ). The estimates of dietary organic matter fermented in the rumen were then obtained by adding the bacterial organic matter to the apparent disappearance of organic matter. There was a significant linear increase in fermentation of dietary organic matter with increasing urea supplementation $(P=0 \cdot 0 \mathrm{r})$. The ratios of bacterial protein to dietary organic matter fermented show no statistically significant differences between treatments. The general mean value was $15.6 \pm 0.7 \mathrm{~g}$ (SE) protein per $100 \mathrm{~g}$ dietary organic matter fermented. This is higher than the earlier values reported (Hungate, 1966 ) but is similar to the I3.3 g reported recently by Hume, Moir \& Somers ( 970 ). Evidence has been provided by Hume (I970) that the values may be even higher when dietary protein is the $\mathrm{N}$ source for the bacteria. Hogan \& Weston (1970) quoted values as high as $3.7 \mathrm{~g} \mathrm{~N}$ (23 g protein) per roo g organic matter fermented.

\section{Protein utilization}

It has been indicated in a number of reports that, under conditions when $\mathrm{N}$ is not limiting, the production of microbial protein is related direct to the quantity of energy fermented (Sharma, Van't Klooster \& Frens, I969; Hume et al. 1970; Hume, I970; Hogan \& Weston, 1970; Ørskov et al. 197 16 ). This idea was discussed by Hungate (x 966 ), and the relationship between cell growth and ATP formation was shown by Bauchop \& Elsden (I960). Since the possible contribution of microbial protein to the animal is fixed in relation to cnergy, it may be profitable to use protein:energy ratios throughout in discussing the ruminant's requirement for protein. Because of its ease of determination, digestible dry-matter intake (DDM) may be a suitable denominator to use in this way. The ratios of $\mathrm{N}$ retention to DDM given in Table 6 show that the lambs had a capacity to retain up to or more than $\mathrm{I} \cdot \mathrm{I} 9 \mathrm{~g} \mathrm{~N} / \mathrm{I} 00 \mathrm{~g} \mathrm{DDM}$, but that the maximum retention from the barley + urea diets was less than I $g$ N/I00 g DDM.

By combining the evidence from Expt 2 regarding the maximum $N$ retention on the barley + urea diets with the evidence from Expt I regarding absorption of protein, a value of $47 \%$ is obtained for the efficiency of utilization of the absorbed protein on these diets. (From values given in Tables 2, 5 and 6 it can be calculated that the mean retention for diets $2 \mathrm{~B}, 2 \mathrm{C}, 2 \mathrm{D}$ and $2 \mathrm{E}$ was $0.93 \mathrm{~g} \mathrm{~N} / 100 \mathrm{~g}$ DDM and that the mean absorption for diets $\mathrm{IB}, \mathrm{IC}$ and I $\mathrm{D}$ was $2.05 \mathrm{~g} \mathrm{~N}$ per Ioo $\mathrm{g}$ digestible organic matter or $\mathrm{r} \cdot 9^{8} \mathrm{~g} \mathrm{~N} / \mathrm{roo} \mathrm{g}$ DDM.)

The authors are grateful to the Home-Grown Cereals Authority for their support. The work was carried out with the technical assistance of $\mathrm{Mr}$ R. Smart and $\mathrm{Mr}$ R. Pirie.

\section{REFERENCES}

Bauchop, T. \& Elsden, S. R. (1960). f. gen. Microbial. 23, 457.

Conway, E. J. (1957). Microdiffusion Analysis and Volumetric Error $4^{\text {th }}$ ed. London: Crosby Lockwood and Son Ltd.

Davidson, J., Mathieson, J. \& Boyne, A. W. (1970). Analyst, Lond. 95, I8I.

Hogan, J. P. \& Weston, R. H. (I970). In Physiology of Digestion and Metabolism in the Ruminant p. 474 [A. T. Phillipson, editor]. Newcastle upon Tyne: Oriel Press Ltd. 
Hume, I. D. (1970). Aust. F. agric. Res, 21, 305.

Hume, I. D., Moir, R. J. \& Somers, M. (I970). Aust. F. agric. Res. 21, 283.

Hungate, R. E. (1966). The Rumen and its Microbes. London: Academic Press.

Hutton, K., Bailey, F. J. \& Annison, E. F. (197r). Br. 7 . Nutr. 25, 165.

MacRae, J. C. \& Armstrong, D. G. (1968). F. Sci. Fd Agric. 19, 578.

Mason, V. C. (r969). F. agric. Sci., Camb. 73, 99.

Mathieson, J. (1970). Proc. Nutr. Soc. 29, 30A.

Orskov, E. R. (1970). Proc. 4th Nutr. Conf. Feed Mfrs, Univ. Nottm p. 20.

Orskov, E. R., Fraser, C. \& Kay, R. N. B. (I969). Br. F. Nutr. 23, 217.

Ørskov, E. R., Fraser, C. \& McDonald, I. (197 I a). Br. F. Nutr. 25, 225.

Ørskov, E. R., Fraser, C. \& McDonald, I. (I97 $b$ ). Br. F. Nutr. 25, 243 .

Sharma, H. R., Van't Klooster, A. Th. \& Frens, A. IM. (Ig69). Z. Tierphysiol. Tievernähr. Futtermittelk. 24, 373 .

Stevenson, A. E. \& Clare, N. T. (1963). N.Z. भl agric. Res. 6, 12 1. 